\title{
The comparison of effectiveness of two variants of preventive anesthesia/analgesia in cancer surgery
}

\author{
Lisnyy I. I. \\ National Cancer Institute, Kyiv, Ukraine
}

\begin{abstract}
Despite modern drugs and technologies in medicine, the questions of adequate analgesia in the postoperative period remain quite relevant. The effectiveness of preventive analgesia in the perioperative period remains a contentious issue.
\end{abstract}

The study included 53 oncosurgical patients. Gr.1 received dexketoprofen in combination with paracetamol for perioperative analgesia before the operation, Gr.2 the same medication was given before closing the operating wound. Anesthesia in both groups included an inhaled (Sevoran) and an extended epidural.

The study showed that the pain intensity on ANI monitoring and the total dose of fentanyl was less in Gr.1, compared to Gr.2. Cortisol plasma level and the level of glycemia in the perioperative period were less in patients in Gr.1 than in Gr.2. Pain intensity after surgery during first postoperative day was lower in Gr.1, then in Gr.2.

The administration of multimodal analgesia with paracetamol and dexketoprofen prior to the surgical interventions provides for the best quality of perioperative analgesia in oncological surgical interventions.

Keywords: preventive analgesia, cortisol, stress response, paracetamol, dexketoprofen.

\section{Introduction}

Inadequate treatment of acute postoperative pain leads to the development of a number of complications that practical doctors do not always associate with insufficient anesthesia. These complications include pulmonary complications with the development of atelectasis, hypoxemia and pneumonia, as well as the development of cardiovascular complications such as hypertension, cardiac arrhythmias and the development of acute coronary syndrome. Inadequate postoperative analgesia increases the risk of thromboembolic complications because of prolonged immobilization. In addition, inadequate postoperative analgesia may increase postoperative mortality, hospitalization duration and treatment costs $[1,2,3]$.

Preemptive or preventive analgesia are currentlyused as methods for adequate perioperative analgesia $[4,5]$. The effectiveness of such approaches is still a discussable question in medical literature. The idea of preventive techniques is that the administration of analgesics before acute noci- ceptive stimulation (surgical incision) will reduce central sensitization in the neurons of the posterior horns of the spinal cord more effectively, compared to the administration of the same drugs introduced after surgical trauma [6]. The intensity of postoperative pain and the need for analgesics should be significantly reduced as a consequence.

By definition, preventive analgesia is the treatment of acute pain that begins before surgery for the reduction of the physiological consequences of afferent nociceptive transmission caused by surgery and prevention of central sensitization [7].

Despite the definition of preventive analgesia is given in the fourth and fifth editions of the guidelines for the treatment of acute postoperative pain [8, 9] researchers often use other definitions (balanced preemptive analgesia, protective analgesia, anti-hyperalgesia, etc.), which creates certain difficulties in interpreting the results of studies on 
preventive analgesia. Therefore conflicting results can be found during the analysis of the available data on the effectiveness and ineffectiveness of this technique [10].

Studies on the effectiveness of preventive techniques for perioperative analgesia with various analgesics continue nowadays. They are focused on non-steroidal anti-inflammatory drugs, opioid analgesics, anticonvulsants (gabapentin, pregabalin), ketamine, and local anesthetics.

We conducted a prospective study of the effectiveness of the administration of NSAID dexketoprofen trometamine in combination with Infulgan (paracetamol) prior to the surgery and compared it to the administration of the same drugs at the end of the operation. We assessed postoperative pain intensity, the need for opioids in the perioperative period and stress response during surgery.

\section{Materials and methods}

A prospective study was performed at the department of anesthesiology and intensive care of the National Cancer Institute (Kyiv). The study included 53 patients with colorectal cancer, according to the ASA II-III. Informed consent of all patients was obtained before the study.

Patients $(n=26)$ with colorectal cancer in stage $\mathrm{T}_{1} \mathrm{~N}_{2} \mathrm{M}_{0}-$ $\mathrm{T}_{2} \mathrm{~N}_{2} \mathrm{M}_{0}$ were included in the study group (Gr.1). They underwent a general anesthesia with sevoflurane in a low-flow technique combined with epidural anesthesia. The epidural block was performed at the $\mathrm{Th}_{10}-\mathrm{Th}_{11}$ level according to a standard procedure. After the test dose, 10-12 ml of a $0.125 \%$ solution of bupivacaine in combination with fentanyl $(50 \mu \mathrm{g})$ were epidurally administered. The prolonged epidural analgesia with a mixture of bupivacaine $0.125 \%$ and fentanyl $1 \mu \mathrm{g} / \mathrm{ml}$ at a rate of $6-10 \mathrm{ml} / \mathrm{h}$ was continued in the postoperative period.

Combined anesthesia based on sevoflurane was performed after the tracheal intubation using the low-flow technique at a concentration of 0.4-1.5 MAC, sufficient to maintain the bispectral index at 40-50. Multimodal analgesia included the administration of dexketoprofen $50 \mathrm{mg}$ and paracetamol (Infulgan) $1000 \mathrm{mg}$ in 25-30 minutes before the surgical incision.

The comparison group (Gr. 2) included patients $(n=27)$ with colorectal cancer in $\mathrm{T}_{2} \mathrm{~N}_{0} \mathrm{M}_{0}-\mathrm{T}_{3} \mathrm{~N}_{2} \mathrm{M}_{0}$ stage. They underwent surgery under general anesthesia with sevoflurane in combination with prolonged epidural analgesia according to the procedure described in Gr.1. Multimodal analgesia included the administration of dexketoprofen $50 \mathrm{mg}$ and paracetamol (Infulgan) $1000 \mathrm{mg}$ at the end of the operation before suturing of the surgical wound.

Fentanyl was used for the intraoperative anesthesia at the recommended doses, depending on the parameters of hemodynamics and BIS. In both groups, muscle relaxation was maintained by atracurium at a dose of $0.1-0.2 \mathrm{mg} / \mathrm{kg}$ under the control of electromyography. The cardiovascular and respiratory systems were monitored intraoperatively: non-invasive blood pressure (mean), heart rate every five minutes, ECG, $\mathrm{SpO}_{2}$, $\mathrm{BIS}$, et $\mathrm{CO}_{2}$, etSev, MAK using the Phillips MP60 monitor.
Patients were transferred at the intensive therapy unit after the surgery. Dexketoprofen $50 \mathrm{mg} 3$ times a day, paracetamol $1000 \mathrm{mg}$ intravenously i.v. 4 times a day and prolonged epidural analgesia with a bupivacaine $0,125 \%$ in the combination with fentanyl $(1 \mu \mathrm{g} / \mathrm{ml})$ at a rate of 6-8 $\mathrm{ml} /$ hour for 3 consecutive postoperative days were prescribed to all patients as a postoperative analgesia.

Main assessment criteria of the study results were: the intraoperative need for analgesics / anesthetics, postoperative pain intensity in 1 hour after the operation and then every 2 hours after during the first day, hemodynamic parameters every 5 minutes, intraoperative pain intensity by ANI monitor (analgesia nociception index) [24] constantly online with a fixation in the card every 5 minutes, the level of sedation with BIS, as well as the level of stress response by determining the cortisol plasma level and the level of glycemia. Cortisol plasma levels and glycemia were assessed before the operation, at the end of the operation and a day after the operation (for glucose).

Cortisol level was determined by radioimmunoassay (RIA) with a set of RIA-cortisol-ST (Belorus) in the scientific research laboratory of clinical immunology of the National Cancer Institute.

Statistical analysis of the results was performed by means of the software "STATISTICA 8.0" (StatSoft, Ink., 2008). An estimate of the distribution of continuous data in groups was carried out by plotting the distribution diagrams, and also by the Kolmogorov - Smirnov criterion. Given that the distribution in the groups was abnormal, a comparison between the groups was conducted using nonparametric methods of data evaluation. The descriptive statistics included average calculi with standard error and $95 \% \mathrm{CI}$, standard deviation, median and quadratic modulus (range between 25 and 75 percentile). The comparison between the groups of quantitative indicators was carried out using the Mann - Whitney criterion, qualitative tests using the two-sided Fisher test. Statistically significant differences were considered for the probability of type 1 error of less than $5 \%(\mathrm{p}<0.05)$.

\section{Study results}

Fifty-three patients were included to the study. Groups did not differ by the disease's stage (TNM classification). Characteristics and perioperative parameters of patients, which were included in the study are presented in Table 1.

Plasma cortisol level before the operation did not differ between the study groups (Fig. 1). Insignificant increase in cortisol level in patients Gr.1 was found at the end of the operation. A significant increase was found at the end of the operation In patients Gr.2 ( $p=0.0017)$, with statistically significant difference with Gr.1 ( $p=0.0033)$.

The level of glycemia before the operation differed insignificantly between study groups. Glucose plasma level increased in both groups by the end of the operation, with a more significant increase in Gr.2 in comparison with Gr.1, $p=450.0033$, and remained elevated to the end of the first day of observation without significant differences between 
Table 1. The characteristics and perioperative parameters of patients included in the study

\begin{tabular}{|c|c|c|c|}
\hline & Gr. $1, n=26$ & Gr. 2, $n=27$ & $\mathrm{p}$ \\
\hline Sex, $m / w$ & $14 / 12$ & $17 / 10$ & 0.822 \\
\hline Age, years & $59.6 \pm 7$ & $60.2 \pm 9$ & 0.4110 \\
\hline Weight, kg & $72.5 \pm 9$ & $78.8 \pm 13$ & 0.4115 \\
\hline ASA, II/III & $20 / 6$ & $21 / 6$ & 1.000 \\
\hline Anterior rectal resection & 13 & 14 & $>0.05$ \\
\hline Proctectomy & 6 & 8 & $>0.05$ \\
\hline Resection of the transverse colon & 7 & 5 & $>0.05$ \\
\hline Duration of anesthesia, min & $211 \pm 59$ & $191 \pm 34$ & 0.2706 \\
\hline Total dose of fentanyl, mcg & $545 \pm 88$ & $672 \pm 228$ & 0.0356 \\
\hline Total dose of muscle relaxants, mg & $95.6 \pm 54$ & $91.4 \pm 39$ & 0.689 \\
\hline Total volume of infusion, $\mathrm{ml}$ & $2570 \pm 319$ & $2166 \pm 325$ & 0.002 \\
\hline The need for sympathomimetics & $2 / 26$ & $2 / 27$ & 1.000 \\
\hline The need for atropine & $0 / 26$ & $1 / 27$ & 1.000 \\
\hline Duration of awakening, min & $8 \pm 2$ & $9 \pm 2$ & 0.1143 \\
\hline
\end{tabular}

the groups. The level of glycemia in both groups, despite a statistically significant increase in the stages of the study, was clinically insignificantly higher than the upper limits of the norm (Fig. 2).

The intraoperative level of sedation in patients Gr.1 was more stable than in Gr.2 (Fig. 3).

Intraoperative assessment of pain intensity according to ANI-monitor showed that patients in Gr.1 the fluctuations of this index were less pronounced in comparison with Gr.2 patients, not exceeding the upper and lower limits of the norm for ANI monitoring (40-70) (Fig. 4).

With a more detailed analysis of the quality of pain relief during anesthesia, the ANI monitor's pain score was calculated below 40 and above 70 points. the frequency of fixation of scores of 40 or less were not detected in pa- tients with Gr.1 (0\%), whereas above 70 the rate of assessments was 86 (34\%). In patients in Gr.2 the rate of fixation of scores below 40 was 23 (7\%), ( $p=0.0001$, when compared with Gr.1), and above 70 this indicator was 99 (30\%), $\mathrm{p}=0.445$ (when compared with Gr.1).

Patients Gr.1 and Gr.2 received prolonged epidural infusion of bupivacaine $0.125 \%$ in combination with fentanyl $1 \mu \mathrm{g} / \mathrm{ml}$ in a complex with multimodal analgesia with Infulgan $4 \mathrm{~g} /$ day and dexketoprofen $50 \mathrm{mg} 3 \mathrm{td}$ in the postoperative period. 7 patients of Gr.1 required additional anesthesia when exceeding the VAS by more than 5 points in the first day after operation, whereas 9 patients in Gr.2 required additional anesthesia, $p=0.780$. In 2 patients, Gr. 1 required the administration of omnopon 2 times, and repeated administration of omnopon was required in 5 patients, $p=0.432$.

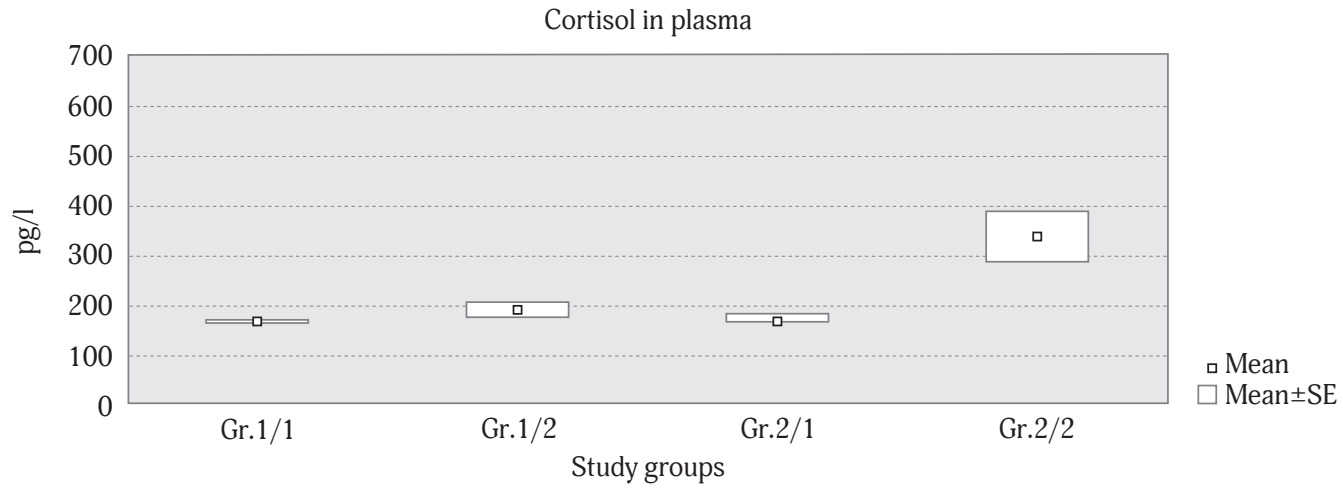

Fig. 1. The change in plasma cortisol in patients Gr.1 and Gr.2 during anesthesia

Note: Gr.1/1 and Gr.2/1 - content of cortisol in plasma before surgery in groups Gr.1 and Gr.2; Gr.1/2 and Gr.2/2 the content of cortisol in the plasma at the end of the operation 


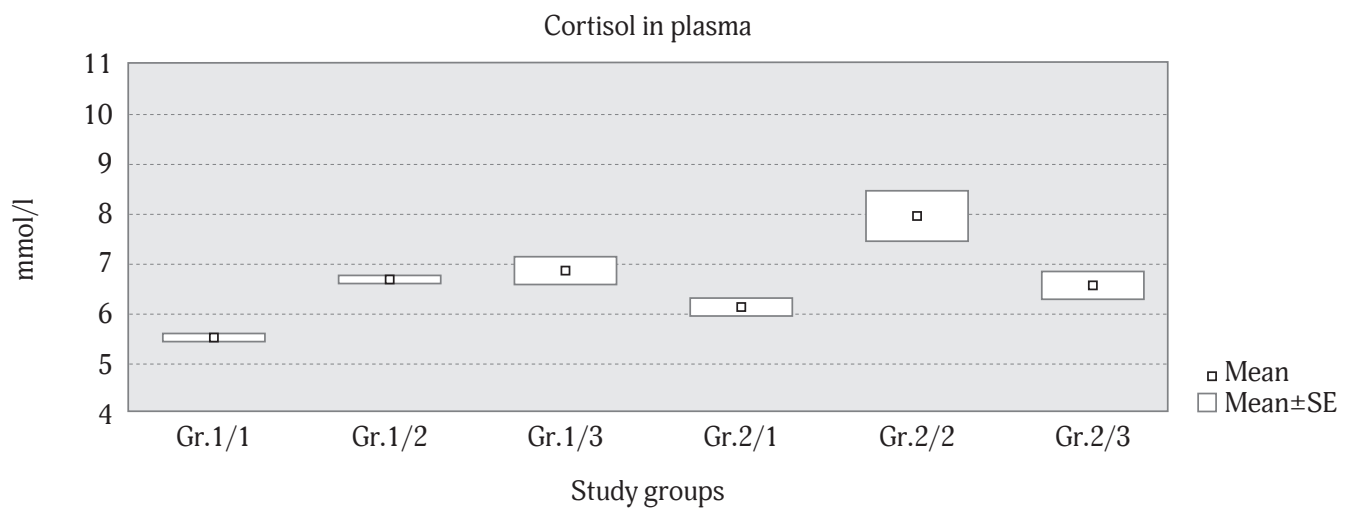

Fig. 2. The changes in the glycemia level in patients Gr.1 and Gr.2 during perioperative period

Note: Gr.1/1, Gr.1/2 and Gr.1/3 glucose in plasma before, at the end and a day after the operation in group Gr.1. Gr.2/1, Gr.2/2 and Gr.2/3 the glucose in plasma before, at the end and a day after the operation in group Gr.2

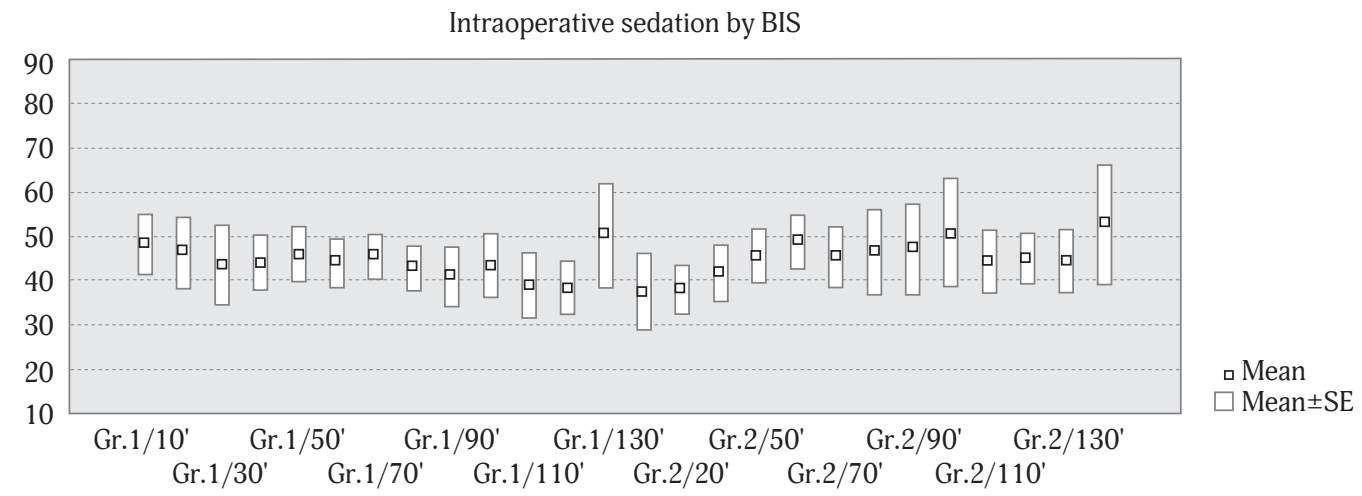

Fig. 3. Changesthe sedationlevel in BIS in patients Gr.1 and Gr.2 during anesthesia

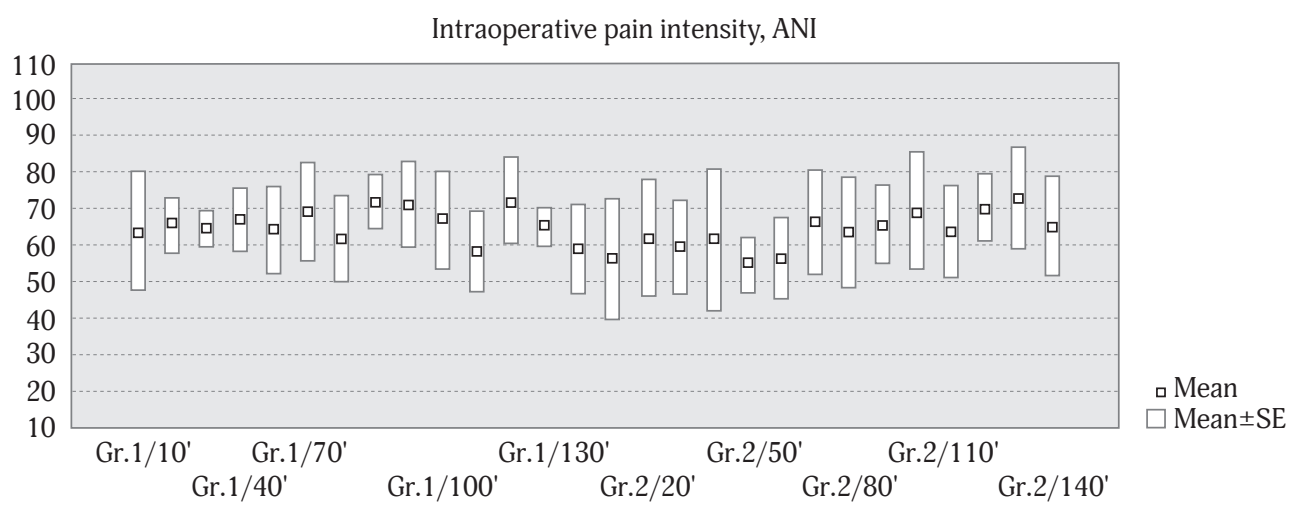

Fig. 4. Assessment of pain intensity according to ANI monitor in patients Gr.1 and Gr.2 during operation

When assessing the intensity of pain in the first 24 hours after the operation on the VAS scale, it was established that in patients Gr.1, the intensity of pain during movement did not exceed 4 points in any control point, whereas in patients with Gr.2 the pain intensity was more than 4 points was noted 6,12 and 18 hours after the operation (Fig. 5).

In a detailed analysis of the adequacy of analgesia in the first postoperative day, a score of 5 or more points in each group of patients was counted. In patients Gr.1, the incidence of pain more than 4 points was 12 from 160 assess- ments for the first postoperativeday, whereas in patients Gr.2 it was 95 from 210, $p=0.0001$.

\section{Discussion}

The idea of preventive analgesia was originally tested in animal models, which showed a change in the plasticity and sensitization of the central nervous system after nociceptive stimulation [11]. The use of analgesics before the application of the pain stimulus could prevent the development of painful hypersensitization and, thereby, reduce the in- 
Pain intensity in postoperative period, VAS

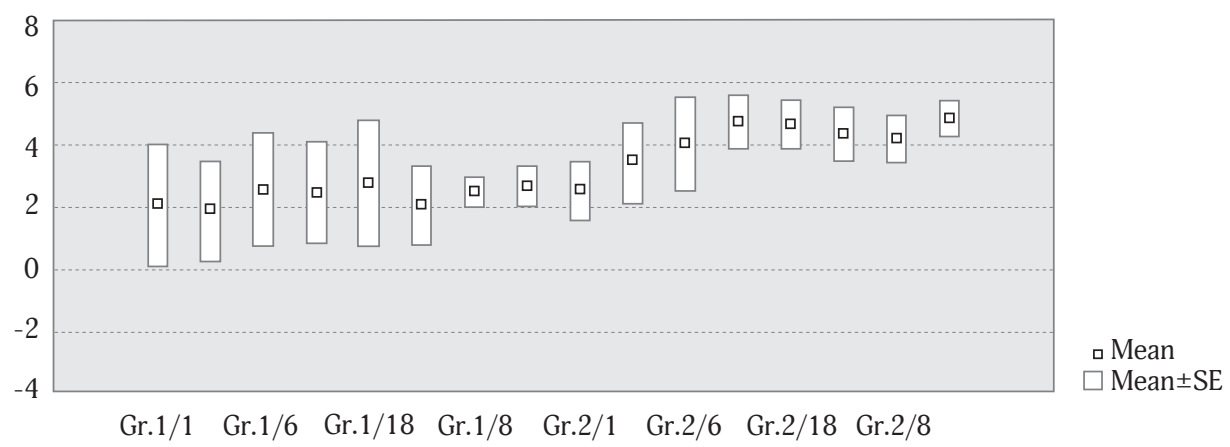

Fig. 5. Changes in pain intensity according to VAS in patients Gr.1 and Gr.2 in early postoperative period

tensity of postoperative pain and the consumption of analgesics. Despite the attractiveness of the idea of preventive analgesia and the positive effect in animal models, research data in humans remain contradictory [12]. Perhaps this is due to the fact that researchers use different versions of preventive analgesia.

For example, a single administration of parecoxib and ketorolac before surgery did not show any advantages over the standard postoperative approach. The authors did not observe a decrease in the dose of opioid analgesics in the postoperative period, a reduction in the frequency of adverse effects of opioids and the time of the first requirement for the administration of analgesics [13]. Other authors made a direct comparison of the efficacy of sodium parecoxib and ketorolac in laparoscopic sterilization [14]. Parecoxib sodium was administered at a dose of $40 \mathrm{mg}$ before surgery, whereas ketorolac was administered at the end of the operation. The authors concluded that parecoxib $40 \mathrm{mg}$ when administered prior to surgery was less effective than ketorolac at a dose of $30 \mathrm{mg}$ when administered in the first hours after surgery.

Despite of the unsatisfactory results of some studies on the effectiveness of preventive analgesia, most of the studies have shown that this approach provide effective in analgesia [15, 16, 17, 18, 19, 20].

Score below 40 (ANI monitoring) was not observed in patients of Gr. 1 , while $7 \%$ of patients in Gr.2 had score below 40 was observed in. So, quality of anesthesia was higher in patients of Gr.1. According to the ANI monitor, a score of less than 40 is considered not adequate anesthesia. Development of hyperalgesia is considered, when the scores are higher than 70 . No statistically significant differences were found when comparing the number of scores greater than 70 points between two groups in our study. It can be assumed that the administration of analgesics (in our study dexketoprofen and paracetamol (Infulgan) prior to the operation provides for a higher quality of analgesia compared with the administration of these drugs at the end of the operation. More effective analgesia in Gr.1 was confirmed by a less pronounced stress response, which was manifest- ed by a lower level of cortisol in plasma and glycemia at the end of the operation compared to Gr. 2.

Average dose of fentanyl during operation was reduced in patients of Gr. 1, who received analgesics prior to the surgery. Opioid saving effect of preventive analgesia has also been established in other studies of the effectiveness of this technique. In a randomized, double-blind, placebocontrolled study, the authors compared the administration of etoroxib $120 \mathrm{mg}$ per os one hour before the operation with its administration after surgery [21]. A decrease in the dose of morphine in the first day after the operation and a better quality of anesthesia without increasing side effects were shown.

It was shown in our study that on the base of more adequate analgesia in Gr.1 during the operation, the sedation level (according to BIS monitoring) was more stable than in patients with Gr.2, although in both groups the sedation level did not go beyond the reference values.

Administration of analgesics before the onset of a surgical trauma contributes to a reduction in the intensity of pain in the first 24 hours after the operation. Pain score was significantly higher in patients Gr.2 in comparison with patients in Gr.1. The need for additional analgesia appeared more frequently in patients in Gr. 2, because of insufficient postoperative analgesia, but this difference was not statistically significant. This confirms once again the situation that the preventive analgesia, started prior to the surgical operation, significantly reduces the intensity of pain in the early postoperative period and reduces the need for additional administration of analgesics. In our study, patients received the same analgesia in the postoperative period - prolonged epidural analgesia in combination with dexketoprofen and paracetamol (Infulgan). Despite this, patients in Gr.2 often experienced postoperative pain (more than four points in the VAS), compared to patients in Gr.1, who used preventive analgesia.

The results of our study once again confirmed the effectiveness of preventive approaches to perioperative anesthesia. Our results coincide with the results of other studies on preventive analgesia. Thus, it was shown in the study, that the administration of paracetamol prior to caesarean 
section significantly improved the quality of analgesia, reduced the intraoperative need for fentanyl and the frequency of side effects of opioids, when compared to the introduction of paracetamol at the end of the operation. The study [23], that was performed in 90 patients after abdominal hysterectomy, showed that administration of paracetamol at a dose of $1 \mathrm{~g}$. 30 minutes prior to surgery significantly reduced the intensity of postoperative pain at rest and during movement, and significantly reduced the dose of morphine in patients with controlled analgesia (PCA), when compared to the administration of paracetamol before operating wound closure. The administration of paracetamol both before and after the end of the operation did not affect the indices of hemodynamics.

We used combination of dexketoprofen and paracetamol (Infulgan) for the preventive analgesia in our study, as important components of multimodal analgesia. According to the latest recommendations for acute postoperative pain treatment [9], multimodal analgesia in combination with NSAIDs and paracetamol should be used routinely.

\section{Conclusions}

The study compared two approaches of preventive analgesia - the administraion of dexketoprofen and paracetamol 30 minutes prior to the operation and administraion of these drugs before closing the surgical wound for surgical interventions in oncoproctology. The study showed that the administration of dexketoprofen and paracetamol (Infulgan) prior to the surgery reduces the intraoperative requirements for fentanyl, contributes to more adequate analgesia during surgery, reduces the intensity of postoperative pain in the first day after the operation, and the need for additional administration of opioid analgesics.

\section{References}

1. Ready LB. Acute pain: lessons learned from 25,000 patients. Reg Anesth Pain Med. 1999 Nov-Dec;24(6):499-505.

2. Pflug AE, Murphy TM, Butler SH, Tucker GT. The Effects of Postoperative Peridural Analgesia on Pulmonary Therapy and Pulmonary Complications. Anesthesiology [Internet]. Ovid Technologies (Wolters Kluwer Health); 1974 Jul;41(1):817. Available from: https://doi.org/10.1097/00000542197407000-00003

3. Kehlet H, Wilmore DW. Multimodal strategies to improve surgical outcome. The American Journal of Surgery [Internet]. Elsevier BV; 2002 Jun;183(6):630-41. Available from: https:// doi.org/10.1016/s0002-9610(02)00866-8

4. Wall PD. The prevention of postoperative pain. Pain. 1988 Jun;33(3):289-90.

5. Lavand'homme P. From Preemptive to Preventive Analgesia. Regional Anesthesia and Pain Medicine [Internet]. BMJ; 2011 Jan;36(1):4-6. Available from: https://doi.org/10.1097/ aap.0b013e31820305b8

6. Woolf CJ. Evidence for a central component of post-injury pain hypersensitivity. Nature [Internet]. Springer Nature; 1983 Dec;306(5944):686-8. Available from: https://doi. org/10.1038/306686a0
7. M iniche S, Kehlet H, Dahl JB. A Qualitative and Quantitative Systematic Review of Preemptive Analgesia for Postoperative Pain Relief. Anesthesiology [Internet]. Ovid Technologies (Wolters Kluwer Health); 2002 Mar;96(3):725-41. Available from: https://doi.org/10.1097/00000542-200203000-00032

8. Macintyre PE, Scott DA, Schug SA, Visser EJ, Walker SM, editors. Acute pain management: scientific evidence. Melbourne: Australian and New Zealand College of Anaesthetists; 2010 May.

9. Schug SA, Palmer GM, Scott DA. Acute pain management: scientific evidence. Fourth Edition, 2015.

10. Wildgaard K, Ravn J, Kehlet H. Chronic post-thoracotomy pain: a critical review of pathogenic mechanisms and strategies for prevention. European Journal of Cardio-Thoracic Surgery [Internet]. Oxford University Press (OUP); 2009 Jul;36(1):170-80. Available from: https://doi.org/10.1016/j. ejcts.2009.02.005

11. Woolf CJ, Wall PD. Morphine-sensitive and morphine-insensitive actions of $\mathrm{C}$-fibre input on the rat spinal cord. Neuroscience Letters [Internet]. Elsevier BV; 1986 Feb;64(2):221-5. Available from: https://doi.org/10.1016/0304-3940(86)90104-7

12. Ong CK-S, Lirk P, Seymour RA, Jenkins BJ. The Efficacy of Preemptive Analgesia for Acute Postoperative Pain Management: A Meta-Analysis. Anesthesia \& Analgesia [Internet]. Ovid Technologies (Wolters Kluwer Health); 2005 Mar;100(3):757-73. Available from: https://doi. org/10.1213/01.ane.0000144428.98767.0e

13. Siribumrungwong K, Cheewakidakarn J, Tangtrakulwanich B, Nimmaanrat S. Comparing parecoxib and ketorolac as preemptive analgesia in patients undergoing posterior lumbar spinal fusion: a prospective randomized double-blinded placebo-controlled trial. BMC Musculoskeletal Disorders [Internet]. Springer Nature; 2015 Mar 18;16(1). Available from: https:// doi.org/10.1186/s12891-015-0522-5

14. Ng A, Temple A, Smith G, Emembolu J. Early analgesic effects of parecoxib versus ketorolac following laparoscopic sterilization: a randomized controlled trial. British Journal of Anaesthesia [Internet]. Elsevier BV; 2004 Jun;92(6):846-9. Available from: https://doi.org/10.1093/bja/aeh161

15. Norman PH, Daley MD, Lindsey RW. Preemptive Analgesic Effects of Ketorolac in Ankle Fracture Surgery. Anesthesiology [Internet]. Ovid Technologies (Wolters Kluwer Health); 2001 Apr;94(4):599-603. Available from: https://doi. org/10.1097/00000542-200104000-00012

16. SAI S, FUJII K, HIRANUMA K, SATO T, NEMOTO T. Preoperative Ampiroxicam Reduces Postoperative Pain after Hand Surgery. Journal of Hand Surgery [Internet]. SAGE Publications; 2001 Aug;26(4):377-9. Available from: https://doi. org/10.1054/jhsb.2000.0520

17. Jebaraj B, Maitra S, Baidya DK, Khanna P. Intravenous Paracetamol Reduces Postoperative Opioid Consumption after Orthopedic Surgery: A Systematic Review of Clinical Trials. Pain Research and Treatment [Internet]. Hindawi Limited; 2013;2013:1-6. Available from: https://doi. org/10.1155/2013/402510

18. Remy C, Marret E, Bonnet F. Effects of acetaminophen on morphine side-effects and consumption after major surgery: meta-analysis of randomized controlled trials. Presented in part at the Annual Meeting of the Soci t Fran aise d'Anesth sie-R animation, Paris, April 2004. British Journal of Anaesthesia [Internet]. Elsevier BV; 2005 Apr;94(4):505-13. Available from: https://doi.org/10.1093/bja/aei085

19. Lin J, Zhang L, Yang H. Perioperative Administration of Selective Cyclooxygenase-2 Inhibitors for Postoperative 
Pain Management in Patients After Total Knee Arthroplasty. The Journal of Arthroplasty [Internet]. Elsevier BV; 2013 Feb;28(2):207-213.e2. Available from: https://doi. org/10.1016/j.arth.2012.04.008

20. Renner B, Walter G, Strauss J, Fromm MF, Zacher J, Brune K. Preoperative administration of etoricoxib in patients undergoing hip replacement causes inhibition of inflammatory mediators and pain relief. European Journal of Pain [Internet]. Wiley; 2011 Dec 19;16(6):838-48. Available from: https://doi. org/10.1002/j.1532-2149.2011.00062.x

21. Munteanu AM, Cionac Florescu S, Anastase DM, Stoica CI. Is there any analgesic benefit from preoperative vs. postoperative administration of etoricoxib in total knee arthroplasty under spinal anaesthesia? European Journal of Anaesthesiology [Internet]. Ovid Technologies (Wolters Kluwer Health); 2016 Nov;33(11):840-5. Available from: https://doi.org/10.1097/

\section{Порівняння ефективності двох варіантів превентивної аналгезії в онкохірургії}

\section{Лісний I. I.}

Національний інститут раку МОЗ України, Київ, Україна

Резюме. Незважаючи на сучасні препарати і технології в медицині, питання адекватного знеболення в післяопераційному періоді залишаються досить актуальними. Ефективність попереджувальної аналгезії в періопераційному періоді залишається спірним питанням.

у дослідження було включено 53 онкохірургічних хворих. Гр.1 для періопераційного знеболювання отримувала декскетопрофен у поєднанні з парацетамолом до початку операції; Гр. 2 така ж медикація проводилася перед зашиванням операційної рани. Анестезія в обох групах включала інгаляиійну (севоран) і продовжену епідуральну.

Дослідження показало, що інтенсивність болю за АНІ-монітором і загальна доза фентанілу були менше в Гр. 1 порівняно з Гр. 2. Рівень кортизолу в плазмі і рівень глікемії в періопераційному періоді були менші у хворих в Гр.1 порівняно з Гр.2.

Проведення попереджувальної мультимодальної аналгезії з парацетамолом і декскетопрофеном при оперативних втручаннях в онкохірургії до початку хірургічного втручання забезпечує кращу якість періопераційного знеболення.

Ключові слова: попереджувальна аналгезія, кортизол, стрес-реакція, парацетамол, декскетопрофен. eja.0000000000000521

22. Hassan HIA. Perioperative analgesic effects of intravenous paracetamol: Preemptive versus preventive analgesia in elective cesarean section. Anesthesia: Essays and Researches [Internet]. Medknow; 2014;8(3):339. Available from: https://doi. org/10.4103/0259-1162.143135

23. Arici S, Gurbet A, T rker G, Yava cao lu B, Sahin S. Preemptive analgesic effects of intravenous paracetamol in total abdominal hysterectomy. Agri. 2009 Apr;21(2):54-61.

24. Jess G, Pogatzki-Zahn EM, Zahn PK, Meyer-Frieem CH. Monitoring heart rate variability to assess experimentally induced pain using the analgesia nociception index. European Journal of Anaesthesiology [Internet]. Ovid Technologies (Wolters Kluwer Health); 2016 Feb;33(2):118-25. Available from: https://doi.org/10.1097/eja.0000000000000304

\section{Сравнение эффективности двух вариантов превентивной аналгезии в онкохирургии}

\section{Лесной И. И.}

Нацииональный институт рака МОЗ Украины, Киев, Украина

Резюме. Несмотря на современные препараты и технологии в медицине, вопросы адекватного обезболивания в послеоперационном периоде остаются достаточно актуальными. Эффективность предупреждающей аналгезии в периоперациионном периоде остается спорным вопросом.

В исследование было включено 53 онкохирургических больных. Гр.1 для периоперационного обезболивания получала декскетопрофен в сочетании с парацетамолом до начала операции; Гр. 2 такая же медикация проводилась перед зашиванием операциионной раны. Анестезия в обеих группах включала ингаляционную (севоран) и продленную эпидуральную.

Исследование показало, что интенсивность боли по АНИмонитору и общая доза фентанила были меньше в Гр. 1 по сравнению с Гр.2. Уровень кортизола в плазме и уровень гликемии в периоперационном периоде были меньше у больных в Гр. 1 по сравнению с Гр. 2.

Проведение предупреждающей мультимодальной аналгезии с парацетамолом и декскетопрофеном при оперативных вмешательствах в онкохирургии до начала хирургического вмешательства обеспечивает лучшее качество периоперациионного обезболивания.

Ключевые слова: предупреждающая аналгезия, кортизол, стресс-реакция, парацетамол, декскетопрофен. 